\title{
The 2020 United Nations human rights treaty body review process: prioritising resources, independence and the domestic state reporting process over rationalising and streamlining treaty bodies
}

Jeremy Sarkin

To cite this article: Jeremy Sarkin (2021) The 2020 United Nations human rights treaty body review process: prioritising resources, independence and the domestic state reporting process over rationalising and streamlining treaty bodies, The International Journal of Human Rights, 25:8, 1301-1327, DOI: 10.1080/13642987.2020.1822337

To link to this article: https://doi.org/10.1080/13642987.2020.1822337

Published online: 09 Oct 2020.

Submit your article to this journal $\square$

Џلll Article views: 818

Q View related articles ¿

View Crossmark data [ד 


\title{
The 2020 United Nations human rights treaty body review process: prioritising resources, independence and the domestic state reporting process over rationalising and streamlining treaty bodies
}

\author{
Jeremy Sarkin \\ NOVA University of Lisbon, Law Faculty, Lisbon, Portugal, University of the Free State, Bloemfontein, South \\ Africa
}

\begin{abstract}
This article reflects concerns about what may emerge from the United Nations human rights treaty body (TB) review process that began in April 2020. The fear specifically is what the outcome of that review may be and whether the goal of strengthening and/ or streamlining TBs will actually result in a less robust state oversight and human rights compliance methodology in the future. Already TBs have been weakened by being granted fewer resources, which causes strains on the system, and by steps to make the procedures easier, less cumbersome, less duplicative, less time-consuming, and less resource-intensive for states. This article maintains, however, that more emphasis ought in fact to be placed on enhancing the resources available to these institutions, and on strengthening their roles in a variety of ways, including by increasing their independence as a means to improve their performance. It claims that if streamlining TBs means reducing what impact these bodies can have, this ought to be avoided. The article also stresses that if the domestic component of the state reporting process is enhanced, and the national follow-up procedures and processes further developed, the TB process will see improvements, both in its functioning and in its role in promoting and protecting human rights in states. It is thus reasoned that the global push to create and promote national reporting mechanisms ought to be supported.
\end{abstract}

\section{ARTICLE HISTORY}

Received 27 May 2020

Accepted 7 September 2020

\section{KEYWORDS}

Treaty bodies; human rights; treaties; state reporting; national mechanisms for reporting and follow-up; United Nations 2020 treaty body review

\section{Introduction}

The 2020 United Nations (UN) review of the functioning of the human rights treaty system, with nine core treaties, ${ }^{1}$ one optional protocol, and 10 treaty bodies (TBs), ${ }^{2}$ began in April 2020. The COVID-19 pandemic scuppered the original plan of the UN Secretary-General (SG), which had been to hold informal consultations in New York by mid-April 2020, with states and in 'the presence of the Chairs of the human rights treaty bodies' (emphasis added), during which the SG would unveil a process to consider how the functioning of the TBs ought to be reformed. However, owing to the pandemic, 
now it will be the role of two ambassadors from Morocco and Switzerland, selected by the president of the UN General Assembly, as co-facilitators of the process, to hold informal consultations with states and to receive 'contributions, as appropriate, from the Office of the High Commissioner for Human Rights (OHCHR), from the treaty bodies, and from other relevant stakeholders.' The co-facilitators are supposed to submit a report to the SG before 30 September 2020. That report is meant to give recommendations on how to 'assess and decide, if appropriate, on further action to strengthen and enhance the effective functioning of the human rights treaty body system'. ${ }^{3}$ This is likely to be the first step in the process to reform the TBs and may result in change to these institutions, whether minimal or maximum, and possibly even to the treaties that they have mandates over.

Thus, the issues of the work of TBs and how they should be reformed are firmly on the UN agenda. These are critical issues, as TBs play a vital role in ensuring state compliance with their human rights duties: the external oversight TBs provide is key to ensuring states live up to their obligations. Their main role is, in an ongoing way, to monitor and ensure compliance ${ }^{4}$ with the relevant treaty ${ }^{5}$ by interpreting it. ${ }^{6}$ They also have a key role in dealing with allegations of non-compliance with treaty provisions. ${ }^{7}$ This is not to argue that TBs are able to ensure compliance in all ways, but at least they shine a light on what a state is doing or not doing in relation to the issues that a given TB's mandate covers.

The role of TBs is of even greater importance when it comes to states that massively violate the rights of their people. While not having any real power to force change, TBs do have various methods and tools to try and ensure states comply with their specific treaty. ${ }^{8}$ Some of them can investigate human rights abuses if serious or systematic abuses are occurring. ${ }^{9}$ Others can take individual and/or state complaints, ${ }^{10}$ if the state has accepted the TB's right to do so. For each treaty, the state's record is reviewed shortly after the state joins that treaty, and it then has to submit a report on its compliance to the TB every few years thereafter. TBs review these state reports, make recommendations to the state in the form of 'Concluding Observations', ${ }^{11}$ and follow up on those recommendations to see how the state has subsequently complied with them. ${ }^{12}$

The present article argues that attempts to reform the TBs are not new by any means, and that various useful reform measures have indeed already been put in place over the last decade or so. This has been done to restructure TBs and make their processes more streamlined and more coherent. However, it is argued that in many ways streamlining and/or strengthening TBs are contradictory aspirations. The case is made, considering the human rights situation in many states, for a continuing and in fact more robust $\mathrm{TB}$ process to ensure that states are more compliant with their international human rights obligations.

This research argues that the TB review process in 2020 ought to place more emphasis on a range of other concerns, such as TB appointment processes (which are controlled by states), resource deficiencies (also an issue under states' control), and enhancing state reporting processes that culminate in reporting at the international level. This is because improvements in these will in turn improve TB processes, and therefore have a positive impact on the performance of TBs. This will lead to a much-improved outcome for the reporting process as whole. 
Thus, the article argues that stressing how national processes can be strengthened in ways that assist TBs in their quest to evaluate state compliance and make recommendations to states, in order to make them more compliant with the human rights standards in the specific treaty, will deliver far better results for the TB process. These enhancements will contribute to the better protection of human rights in states. It is argued therefore that the 2020 review process ought to focus much more on the establishment of open and transparent state reporting processes at the national level, including the creation of specific national reporting mechanisms. The roles of these national mechanisms are therefore examined to determine how these bodies, which should ideally function in participatory and democratic ways, can benefit both TBs and the state in which they operate.

This article treats TBs collectively for the purpose of this research, even though each treaty, and each treaty body, is different. However their processes, procedures and the issues that affect them all are pretty much the same, with some limited differentiations. Additionally, the UN review process is dealing with all the TBs together. Thus, the emphasis of the present research is on the generalities and similarities of TBs, and the issues and ways in which they work communally, rather than on the individual intricacies of each, which are not really important for the purpose of this article.

\section{The importance of the human rights TB processes in ensuring state human rights compliance}

Generally, the promotion and protection of human rights in a specific state are seen to be the duty of that state. However, many states do not always carry out their duties sufficiently and others actually abuse the human rights of their inhabitants. Even societies that are fairly human rights-compliant have human rights problems. It was the case until relatively recently that the prevalent view, although not correct, was that human rights inside a state remained within the purview of that state, with some exceptions. Today that view no longer holds as much water. Human rights, generally, is no longer understood to be only a matter for the state concerned but one where others may intervene on occasion and where a number of players have responsibilities. ${ }^{13}$ This is because most states no longer see human rights matters as falling within the internal domestic affairs of a state alone. ${ }^{14}$ While some states do at times continue to make the argument that state sovereignty implies that human rights matters are not subject to the purview of others, the reality is that such arguments are no longer widely accepted and are merely a means for such states to try and avoid criticism of their actions. As Cassese has argued,

State Sovereignty is not unfettered. Many international rules restrict it. In addition to treaty rules, which of course vary from State to State, limitations are imposed upon State sovereignty by customary rules. They are the natural legal consequence of the obligation to respect the sovereignty of other States. ${ }^{15}$

Even countries that attempt to avoid scrutiny have in fact accepted oversight processes, voluntarily, on many occasions. Indeed, even the staunchest advocates of state sovereignty accept scrutiny and comply with processes that hold them accountable as regards their human rights obligations, many of which have been freely assumed. ${ }^{16}$

States accept inspection in a variety of ways, including by joining institutions that have mandatory review processes as a part of their institutional makeup. ${ }^{17}$ Thus, a state has a 
choice. It can join an institution if it wishes. However, on doing so, it accepts the rules of that institution, including its human rights rules. It also thereby accepts the rules that mandate oversight and review processes to ensure compliance. Another voluntary way that states accept oversight and review is by joining treaties. Ratifying a treaty produces obligations for any state that does so, which all states do, to different degrees: there is no state that has not ratified at least some human rights treaties, even including some of the most egregious violators of human rights, such as North Korea, Syria, China, Burundi, Belarus, and so on. As a result of these treaty obligations, states have a duty to promote and protect human rights domestically. Under each treaty that they have ratified, they have responsibilities to ensure that the rules from those treaties are brought into the laws of their country and those laws are complied with by the people in that state. ${ }^{18}$

Within that context, the TB process must be seen as part of the apparatus for holding states accountable as regards their human rights obligations. It is just one of the pieces of the jigsaw of states' reporting and oversight obligations, but it is most extensive in the area of human rights. Therefore, looked at another way, human rights is also the area where the TB process should have the most impact.

The TB process is a voluntary one, as states decide themselves whether to join a treaty or not. Very few states withdraw from these treaties at a later stage, which reflects the extent to which states largely accept these processes. That said, there has recently been pushback against certain institutions with oversight and compliance responsibilities regarding human rights, and indeed against oversight mechanisms in general. ${ }^{19}$ While there had previously been a tendency towards expanding the mandates of such institutions - and in fact a push to expand the jurisdiction of some, like giving the African Court criminal jurisdiction - lately the reverse has been true. There has, in fact, been a backlash or pushback against a number of courts. ${ }^{20}$ For example, some states in Africa have been withdrawing their acceptance of the African Court's jurisdiction to hear complaints from non-governmental organisations (NGOs) and individuals. ${ }^{21}$ This defiance has occurred not only in African regional and sub-regional courts ${ }^{22}$ (including the decimation of the Southern African Development Community Tribunal), ${ }^{23}$ but also in Europe, ${ }^{24}$ owing to states' unhappiness with some of these courts' decisions. ${ }^{25}$ Other processes, such as the World Trade Organization (WTO) appellate body, also have had steps taken against them to curb their powers. ${ }^{26}$ Elsewhere in the UN, states have also been taking steps to limit the extent of the oversight processes over them, such as at Universal Peer Review (UPR). ${ }^{27}$ Thus, pushback seems to be a growing trend.

Therefore, a key question is what the situation regarding treaty compliance is. Indeed, TB effectiveness is still questioned, and some argue that 'human rights treaties do not systematically improve human rights outcomes'. ${ }^{28}$ Problematically, these processes are not sufficiently scrutinised to determine levels of state compliance. Thus, Hathaway has stated: 'Human rights law thus stands out as an area of international law in which countries have little incentive to police noncompliance with treaties or norms. ${ }^{29}$ It is also important to bear in mind that, as Hathaway has argued, 'full democracies appear to be more likely to comply with their human rights treaty obligations than the group of nations as a whole' ${ }^{30}$ It has also been argued that the human rights scorecard of a state gives a good indication of the extent to which that state will comply with the recommendations made to it. ${ }^{31}$ 
Significantly, there are challenges to the TB processes achieving the desired impact. States' compliance levels with these processes ${ }^{32}$ and with implementing the recommendations made to them by TBs are in general low. ${ }^{33}$ In 2010 , the implementation rate of recommendations made to states by the Human Rights Committee (HRC), ${ }^{34}$ resulting from petitions to it, were determined to be 'grim': it was found to be $12-15$ per cent. ${ }^{35}$ This problem has persisted for some years, and indeed has worsened over time: almost a decade earlier, in 2001, a report already found that HRC compliance by states was 'extremely poor' and that remedies were provided for in only 21 per cent of the matters. ${ }^{36}$ An Open Society Justice Initiative (OSJI) report found that implementation rates had halved between 1999 and 2010, although it was noted that the Committee Against Torture (CAT) petition process had a 50 per cent implementation rate. ${ }^{37}$

These issues are significant for understanding the situation that TBs find themselves in. There have long been arguments that the low compliance levels are a reflection of a lack of commitment by states to the TB process. Crucially, at least part of the reason for such low levels of compliance is TBs' inability to enforce compliance ${ }^{38}$ and their lack of sanctioning powers. ${ }^{39}$ There is also the issue of resistance to the outcomes, as the findings and recommendations are seen by states to be voluntary in nature. ${ }^{40}$ It is also true that the lack of compliance by states is a reflection of states having insufficient information on the issues and a lack of capacity to effect the changes. ${ }^{41}$ However, as argued by Thomas Buergenthal as early as 2001, a 'Committee determination that a state has violated a right guaranteed in the Covenant therefore enjoys a normative and institutional legitimacy that carries with it a justifiable expectation of compliance'. ${ }^{42}$

The reasons for state non-compliance are manifold. Some states have no desire to really be compliant, while for others the costs of compliance are too high. Dutton for example argues that a state's commitment to international human rights treaties is a result of

two considerations relative to the costs of noncompliance: (1) the institutional design of the treaty - specifically, the level of enforcement mechanisms to punish noncompliance; and (2) the state's domestic political characteristics relating to its ability to comply with treaty terms. ${ }^{43}$

While Dutton argues that it is important to examine how human rights friendly the state is, the argument made here is that it is also important to examine whether the mechanisms that exist in that state are able to effectively to ensure state compliance and whether they have appropriately designed mechanisms to ensure that. In other words, is the process to deal with reporting and follow-up effective and likely to ensure the best outcomes? States that do not have mechanisms to ensure reporting and follow-up are less likely to be successful in implementing TB recommendations. This is not to discount the other variables in explaining whether states are likely to comply, but to assert that the domestic situation of a state, in many different ways, including how it deals with recommendations and what process it undertakes, is a major factor in how it complies with those recommendations. These issues are taken up below.

\section{Reforming TB processes}

For a long time, problems have been raised about the TB reporting processes and suggestions made about how to improve them. ${ }^{44}$ Demands for change have often come from 
states, which have argued that these processes are onerous on them. TB processes are seen by them to be cumbersome, duplicative, time-consuming and expensive. There are concerns that they do not sufficiently achieve what they ought to be achieving. ${ }^{45} \mathrm{It}$ is also argued that the TB system as a whole is under strain because the number of states that need to be reviewed overall, and therefore each year, has grown over time.

\subsection{The growth of the TB processes over time}

Indeed, the overall number of ratifications of human rights treaties and protocols, in addition to declarations that allow communications and inquiries to be made of states within the UN, collectively, when adding up all states that need to go through these processes, was 2,451 at the end of October 2019. This was an increase from 2,386 at the end of December 2017 and up from 2,190 in 2013. This means that each UN member state generally has many human rights reporting and follow-up processes to undergo. It must also be noted that very few states do not have such processes. There are very few non-member states of the UN, such as the Holy See and Palestine, as well as a handful of other states whose situation and sovereignty status are disputed and as a result are not part of the UN. However, overall almost every state has many reporting obligations (including human rights reporting obligations) to the UN, as well as to other institutions.

\subsection{Strains on the system and strains for states}

The problem of a strained TB system that has grown over time is compounded by the fact that the time involved to conduct these reviews is limited by the number of weeks the TBs are able to meet for. While the time allocated for TBs to meet increased in 2019 to 93 weeks a year collectively, ${ }^{46}$ that is still not enough time to deal with all the many processes. As a result of this insufficient time, there have been long time lags between the submission of reports and the process to actually deal with them - sometimes as long as seven years. ${ }^{47}$

States also complain that they have difficulties in managing their reporting requirements. This can be seen by the fact only 38 of 197 states parties, or 19 per cent, had no outstanding reports from TB processes; in other words, 81 per cent of states did have at least one report outstanding. What is more, some reports have been overdue for more than 10 years. The number of outstanding reports varies by TB but to some extent reflects the numbers of ratifications. States might be able to manage their reporting requirements better if they devote more resources and time to these processes; however, the fact that they generally have not is to some extent a reflection of a desire for the process not to work optimally.

\subsection{Resources}

The resource limitation issue has been increasing over time. While the number of treaties has increased, the resources available to TBs to operate have stayed about the same. However, now the amount of resources is in fact declining and the UN has put resource-saving measures in place to save money. The UN TB system has been 
dramatically affected by resource limitations in 2019 and $2020{ }^{48}$ As a previous High Commissioner noted, TBs were informed that:

they would not be able to meet as normal for their autumn sessions - these were to be cancelled ... [and] they should expect fewer, not additional, resources in future UN budgets. They [TBs] are barely able to keep on top of the reports States submit, even though $80 \%$ of these reports are late; if States submitted on time, the treaty bodies would be overwhelmed. Yet, over the years there has been a cold indifference to their pleas for more resources. ${ }^{49}$

Another way in which resource limitations deeply affect the efficacy of TB processes is that the OHCHR is able to devote very few staff members to support such processes. ${ }^{50}$ In fact, OHCHR resources in general have declined over time. This damages all the institutions that the OHCHR supports, including, for example, Special Procedures. Thus, the resource and other limitations mean that the members of TBs are not able to engage with these processes sufficiently. In particular, they may not be able to get all the information they need to engage in proper oversight and make all the recommendations required to ensure compliance, ${ }^{51}$ and have often relied on others, such as NGOs, to provide such further information. Ramping up engagement at the state level should lead to much more information being forthcoming, as more people will know about these processes and therefore be more likely to engage with them.

If resources were not a problem, then having more time and allowing meetings to happen in regions or even in states where a review was taking place would heighten knowledge, experience and engagement with the processes. It would also create more dynamism for local processes. Thus, part of the way forward involves identifying how to provide more resources to a stretched system. While resources are not the only problem, they impact severely on the workability of the system. ${ }^{52}$

\subsection{Strategies implemented already}

To deal with the range of problems that exist with the TB process, various strategies have been introduced over a number of years to assist the reporting process. In the past, the fact that each treaty had a different process and different requirements had been seen to be problematic for many years and in need of reform. ${ }^{53}$ This has changed to a large extent. Now there are synchronised reporting guidelines across all the treaty processes, a simplified reporting procedure, and the use by some committees of a 'List of Issues Prior to Reporting' (LOIPR) to ensure focus and avoid redundancy. In addition, supporting other stakeholders so they can also engage in the reporting process has been recognised as being key, as has the necessity of working with states to enhance and improve their capacities with regard to these processes. ${ }^{54}$ These need much more effort, and much more of a focus, as will be delineated below.

\section{The problems with rationalising, streamlining and/or strengthening TBs}

Reforming the treaty system has been the subject of discussion for a long time. ${ }^{55}$ In 2009 , then High Commissioner for Human Rights Navi Pillay called for the system to be 
'streamlined and strengthened'. ${ }^{56}$ By resolution 66/254 of 23 February 2012, the UN Economic and Social Council thus set in motion an intergovernmental process in the General Assembly to strengthen and enhance the efficient performance of the human rights TB system. In 2014, the General Assembly adopted a resolution on TB strengthening. ${ }^{57}$ It decided to review the condition of the human rights TB system within six years (that is, in 2020), to assess the efficiency of actions taken and to deliberate on steps that should be taken to reinforce and improve the successful performance of the system. ${ }^{58}$ Thus, the process to be undertaken in 2020 by the General Assembly is meant to deal with how the TB system ought to be reformed and made more efficient.

However, in some ways, these two concepts (streamlining and strengthening) are mutually incompatible. Streamlining can ensure that a process becomes less able to achieve what it did previously. ${ }^{59}$ Strengthening can mean that more is achieved, more resources are allocated, more time is allocated, more tools are available, and so on, ${ }^{60}$ but the term could equally in fact be used rhetorically and end up having the opposite effect in reality. However, taking the literal meaning of the words, achieving both streamlining and strengthening at the same time is unlikely. While these concepts continue to be used, they should be understood more clearly, and in fact the dangers that may result need to be considered.

Egan has noted for example that 'the strengthening process clearly reflects a developing consensus that meaningful improvement of the treaty body system and enhancing its $\operatorname{impact}^{61}$ (emphasis added) are being sought. However, that states wish to enhance the impact of TBs seems a stretch, particularly from the vantage point that at least some states see the reform process as a means to reduce the efficacy of the TB process. As Helfer has noted:

In the best case scenario, these efforts will lead to more effective and efficient monitoring mechanisms. However, in an era when challenges to international institutions are on the rise, there is a non-trivial risk that 'strengthening' processes could in fact lead to the opposite result - weakened and less impactful systems of international supervision and monitoring. ${ }^{62}$

That there may be some attempts to weaken the TB system can be seen to some extent in a Non-Paper for the 2020 review of the UN human rights TB system, submitted by Costa Rica and 43 other states, which had wide-ranging suggestions for TB reform. ${ }^{63}$ Many were very positive, including on such matters as: predictability and appropriate periodicity of the TB processes; the accessibility and harmonisation of the processes; the role of the Secretariat; coordination within the UN system and with regional mechanisms; insufficient resources; independence, competence and impartiality of the members of the TBs; and the responsibilities of states parties, including in relation to non-compliance, the independence of the system, the role of civil society, and reprisals. However, one of the worrying suggestions was about having a simplified reporting procedure, which could mean reducing the thoroughness of the process. Another disturbing suggestion was for the dialogue between TBs and states to be contextualised and more focused (e.g. by limiting the number of questions raised by the experts) and a more constructive narrative should be used in order to pursue a positive impact on the ground through implementation'. Obviously, the following view has not been sufficiently understood or accepted: ' $t$ ] he report-and-review process is a dialogue - not an exam and certainly not a trial. It is an opportunity for 
States to learn about best implementation practices or more efficient and effective methods to improve treaty outcomes' ${ }^{64}$

In this regard, lessons can be learnt from other processes as to how to assist state reporting processes for human rights, especially with respect to issues concerning the dialogue process that occurs between the TB and the state. For example, it has been argued that the multilateral agreements and processes in the area of environmental protection, with their various compliance methods, provide 'a political solution through gentle political pressure, consultation, and negotiations' ${ }^{65}$ Thus, because the dialogue process is a source of concern for states, how it is conducted ought to be taken up by TBs. Training also ought to be provided to TB members on the best ways to conduct the dialogue, how questions should be asked and how the discussion ought to be conducted, but for other items in the reporting process as well.

However, steps should not be taken by the TB review to reduce or limit the dialogue between states and the TBs. Weakening or restricting the dialogue between TBs and states would decrease the information available, reduce the understanding of the situation in a specific state, and thereby reduce the effectiveness of the process. Of most concern was the suggestion that 'recommendations should be more measurable, achievable and strategically focused on a limited set of issues. Recommendations should be based on facts and substantial grounds with sources'. This, if adopted, would severely undercut the roles of TBs, particularly if the number of issues raised were reduced. These suggestions would streamline the TB processes, but certainly not strengthen them; in fact, they would severely weaken the processes if they were to be taken up.

Thus the question must be asked whether in the quest for easier and simpler reporting processes the result might be a reduction in the ability of TBs to protect human rights. ${ }^{66}$ If the process is not as thorough, not as extensive, not permitting as wide a review of the issues as possible, can the results be as robust? If the process is not as dynamic as possible, and not at least as strong as it was previously, then can the outcome be as useful? Will the result of the process not suffer as a result of a somewhat simplified and less intensive process? While items such as a LOIPR can be beneficial by focusing attention on some key issues, it does mean that other issues not raised by the TB, which may well also be problematic, are not focused on and can in fact at times be avoided.

If streamlining is the goal of the review process (that is, limiting the extent of the process and the recommendations that emanate from it), then this will not be acceptable to those who want the process to achieve a greater impact on the human rights situation in a particular state. However, if strengthening the process is the goal, then, with some reservations from states, this would make the process far more robust in ensuring state compliance. In this regard, the former High Commissioner of Human Rights has noted that: 'Reform could result in a system that is less burdensome in terms of reporting, and better informed to advise States on reforms. That should be a welcome result for all. ${ }^{67}$ However, this statement is in fact contradictory, as having a less burdensome system is unlikely to lead to the process being better informed. In fact, just the opposite is probable. Nevertheless, her emphasis is on reporting in the future being less burdensome. That could mean, unfortunately, that less information would be supplied to the TB and that TB recommendations could be less onerous. That would be an undesirable outcome of the reform process, as it would have the effect of hollowing out the TB process rather than the intended goal of strengthening what it does and what it achieves. 
The more important question in determining what reforms are made ought to be how to make the process have greater impact. ${ }^{68}$ Specifically, greater human rights protection is needed. ${ }^{69}$ Reforms aimed simply at saving states and the UN time and money should not come at the expense of a decline in the important human rights improvement roles played by the TB system. Thus, while rationalising or optimising the system is important, the central concern in the treaty review process ought to be how the system can ensure that states are carrying out their human rights obligations more effectively. ${ }^{70}$ While it is true that having 10 TBs creates difficulties for states because of the many resulting reporting obligations, and is costly and at times duplicative, moving to a process that reduces the extent and frequency of oversight, in part by lumping TB processes together, will only negatively affect the impact the TBs will have.

Therefore, if states allocated more resources to TBs, a better approach would in fact be to provide more time for TB processes, not less. ${ }^{71}$ Hand in hand with this, if TB committee members were to be paid for their participation in the process, it would allow them to devote more time to it. This is not to argue that TB membership should become a fulltime endeavour. ${ }^{72}$ However, TBs already demand substantial time from committee members, and if more time were to be asked of them, ways to support them, specifically financially, would need to be found. There has been an argument that paying TB members for their time will make these individuals less independent, ${ }^{73}$ and although it could affect their independence depending on how the payment process is set up and administered, it should not really be the case. Admittedly, the role of the OHCHR in administering TBs already affects the independence of the process. Thus, if TB members are to be paid, it should be a daily fee for their time spent working in a specific TB system, and not be administered by OHCHR. One method to enhance the independence of the system would be to create an administrative and support system outside of the OHCHR. As will be discussed later, other steps need to be taken to enhance the independence of TB members and reduce the politics in their appointment.

Given that states often complain about the time and resources they need to devote to TB processes, especially small states, ${ }^{74}$ the answer might seem to be to provide the resources to allow them to cope. Additionally, a range of alternatives to the present system could be used to reallocate resources for other purposes. For example, having some online meetings would save huge amounts of resources, not least in terms of the costs associated with TB members' travel and per diems paid for living away from home. It would also save states having to send lots of people to Geneva. However, fundamentally, more resources ought to be given to TBs to do their work.

As far as states' complaints about the time they need to devote to these processes are concerned, there have long been calls to ensure that states do not have to report more than twice a year. ${ }^{75}$ This is feasible: if a state has ratified all $10 \mathrm{TBs}$, it should not have to provide more than two reports a year over a five-year period. ${ }^{76}$ The process will however suffer if, as is being suggested, TBs collectively review a state every eight years, or half of them do so every four years. This would then see a 'single state report combined with a consolidated state review' or a 'semi-consolidated state report combined with a clustered state review'. ${ }^{77}$

Thus, while there are many reasons to embark on reforming the TB process, the key questions ought to be what type of reforms are needed and what should be done to achieve those reforms. A critical issue is to ensure the reforms do not reduce the 
impact that each TB will have on human rights matters in states. The TB processes should be dynamic. While finding better and more efficient ways for TBs to work should be an ongoing concern, a more central issue that ought to be given attention is how TBs can have greater impact on states' human rights issues. Part of that is to ensure that a greater focus is placed on the domestic state reporting process and how TBs can be better served by states in their quest to enhance human rights protection.

\section{Emphasising the role of the domestic reporting process in the TB process}

Until now, much of the emphasis on reforming the TB process has been on doing so inside the mechanisms seated in Geneva, with little attention being given to how state reporting processes can be assisted by what happens inside states themselves, and to how what happens there can be more helpful to TBs.

\subsection{The quality of state reports}

A key issue that ought to receive more attention is the quality of state reports. If the quality of these reports improves, then the TBs in turn have more of what they need to improve their own work, and would be able to do it more quickly and easily. Moreover, they would be able to come up with better recommendations to improve the issues of concern in a certain state.

Some have argued that the quality of the reports 'submitted by States varies. Some reports reflect serious efforts to comply with the reporting requirements, while others lack credibility. ${ }^{78}$ Others have held that the quality of some state reports is poor. ${ }^{79}$ State reporting in the past has been seen to 'tend to be descriptive, formalistic, legalistic and self-congratulatory, rather than reflective and focused on substance and practical realities, and problems encountered'. ${ }^{80}$ Suffice it to say the quality of state reports to TBs from different countries varies enormously. Indeed, this was already noted by the OHCHR early in the process of reviewing TBs, in $2006 .{ }^{81}$ It is true, however, that '[r]eporting quality has not been investigated systematically to date'. ${ }^{82}$ It has been noted that:

it is debatable whether governments even take the report drafting process seriously ... As States have little to no incentive to report, spotty reporting is unsurprising. More cynically, the system provides few inducements to report thoroughly: States may selectively provide requested information, present information in a way that obscures the situation on the ground, or ignore concerns or questions posed by the treaty body. ${ }^{83}$

Thus, crucially, until a system is put in place to enhance the quality of reports, streamlining the reporting process contains the danger of reducing its efficacy. This is because it would mean that the TB has even less to work with in the future. As noted above, some reports are not up to the standard necessary to give TBs sufficient information to do their work optimally, in terms of analysing the situation in that state and making the necessary recommendations. The effectiveness of the TB process is thus directly linked to the quality of the state reports and the ability of a TB to make real and effective recommendations that are then implemented in the state concerned. ${ }^{84}$ 
Thus, a key issue is how to optimise state reports to better assist TBs. Crucially, for the recommendations and follow-up process to be meaningfully taken up and successfully implemented by states, ${ }^{85}$ there needs to be a methodology for doing so. ${ }^{86}$ This means there cannot be ad hoc processes anymore to deal with what comes from the external body. There needs to be an ongoing standing procedure to manage those processes effectively and efficiently.

\subsection{Increasing awareness of domestic processes}

One of the major problems with the state reporting process - both to TBs and other external mechanisms - is that it is generally not known about. ${ }^{87}$ Reporting is usually left to the state's ministry of foreign affairs (MFA) to deal with; within the wider government, there is generally little knowledge about how the reporting process works. Even when the MFA engages with other ministries in relation to TB reporting, it is usually on limited matters. While other ministries, such as the justice ministry, are often considered to be closer to the issues, they are frequently simply consulted rather than playing a part in engaging with the external body. Consequently, the fact that there is so little knowledge and awareness of these practices and processes domestically, and of their importance, deeply affects the whole state reporting process, both in the individual state but also for TBs, as it leads to scant interest or understanding of how states engage with these external institutions.

Thus, it is without doubt that states need assistance, generally speaking, to deal with their reporting obligations and with what emerges from those processes. Thus, institutional mechanisms for state reporting and follow-up are today essential. No longer can different people take up the reporting process in different ways, in different state ministries, each time a state goes through such a process. Institutional memory needs to be captured and long-term expertise and skills built up. Creating an institutional home which has an ongoing responsibility for managing these processes can do this.

$\mathrm{TB}$ processes also need to be more visible and accessible on a domestic level. As a former High Commissioner for Human Rights has noted, TBs

could be even more effective if measures were put in place ... to better publicise their work, to bring them into more direct contact with civil society and government reformers on the ground, and to ensure proper follow-up to the recommendations they make. ${ }^{88}$

This is similar to what the chairs of TBs themselves suggested when they called for 'a simplified system that would be more coordinated, internally aligned and accessible to States, civil society and victims of human rights violations... [and] proposed to take treaty bodies closer to people'. ${ }^{89}$ Another suggestion has been for best practices between states to be made more available to other states. ${ }^{90}$

In regard to ensuring state compliance, Chayes and Chayes have argued that 'the fundamental instrument for maintaining compliance with treaties at an acceptable level is through the iterative process of discourse among the parties, the treaty organisation, and the wider public'. ${ }^{91}$ Thus, promoting awareness and engagement with the treaty reporting process, both at the international and domestic levels, is crucial to ensure that these processes have more effect and states comply with the outcomes of the reporting process. Thus, there is a duty on a variety of actors including the UN, TBs, states and 
others, to ensure that reporting processes become far more widely known about. Obviously, knowledge and interest on the part of the public in states where compliance is sought are crucial. Thus, information about the reporting process, how it works, the timetable, how to access it, how to provide shadow information, lists of questions, findings, recommendations and many more issues ought to be much more accessible to the public. This will have enormous benefits. It has already been taken up to some extent, but much more is needed.

\subsection{Involvement of the UN}

Until recently there has been very little emphasis by the international community on the national reporting process - but this is changing. The UN is embarking on steps to assist these processes and specifically to help in the creation of national mechanisms for reporting and follow-up..$^{92}$

The UN has already taken up the issue of state reporting. However, its role at the domestic level was limited until quite recently. Previously, the UN's focus on human rights improvement at a domestic level was more related to matters such as the development of human rights indicators and benchmarks, ${ }^{93}$ which would indirectly assist state reporting. However, for about the last five years or so, the UN has also been concentrating on the domestic aspects of the reporting process. ${ }^{94}$ Part of that emerged from the ongoing process in the UN to reform the TB system. ${ }^{95}$ Thus, there has been a focus on how domestic processes can be better aligned so as to assist the TBs. The OHCHR has been working on getting states to create dedicated state reporting mechanisms and to embark on reforming their reporting practices. ${ }^{96}$ This was a result of one of the requests in the 2014 General Assembly resolution on strengthening TBs. That resolution called on the OHCHR to 'support States parties in building the capacity to implement their treaty obligations and to provide in this regard advisory services, technical assistance and capacity-building'. Subsequently, the SG reported in 2020 that in two years, ending in October 2019, the UN had provided training and support to officials in 95 states, delivered some 285 events with around 3,830 participants, assisted in growing the understanding and skills on a variety of treaties, stimulated new ratifications, and got outstanding state reports to be submitted in a more timely fashion. However, the aforementioned training for officials seems to have generally been on treaties and not on reporting. ${ }^{97}$

The OHCHR has also been assisting states in preparing their reports to TBs. However, it should assist in all phases of the reporting and follow-up process. This is important because if there were more functional state reporting processes in more states, it would benefit the visibility of such processes. It would also ensure more knowledge about TBs and the role they play. This would have important effects, including allowing more people to be aware of how nominations to TBs are made by states.

\subsection{Democratisation and diversification of TBS}

The issue of diversity amongst the membership of TB committees - including problems of gender parity, regional diversity ${ }^{98}$ and the need to involve more people from groups most affected by the work of TBs - has been an ongoing one. These problems arise from the setup of the election process for TBs. An example of this can be seen in the 
election of the Committee on Enforced Disappearances (CED), which monitors the implementation of the International Convention for the Protection of all Persons from Enforced Disappearance. This Convention entered into force in 2010. In 2011, when elections to the CED were held for the first time, there were just 10 state nominations for 10 places on the Committee. For the first election cycle, this could be explained to some extent as being a result of the Convention having just come into force and only having received a limited number of ratifications. However, in the subsequent replacement election cycles for members of the CED, there have still been very few nominations. Often there have been exactly the same numbers of people nominated for the number of vacancies available on the CED. Thus, in 2019 (when there were about 60 state parties) there were just six nominations for five places, but one withdrew, and thus all the nominated candidates were elected.

The major problem is that these elections are usually (but not always) shrouded in secrecy at the domestic level, or at least completely unknown to the general public. The fact that national appointments usually do not have an open appointment process and the government chooses from only one or two candidates makes the domestic process very weak. ${ }^{99}$ Moreover, the fact that relatively few states nominate candidates to TBs then compounds the weakness of the selection process as a whole. These problems are even further exacerbated in some committees where people serve extended terms because of few alternative nominations. Even lawyers, or others who take a specific interest in these matters, generally only find out about a state candidate after the state has decided who their contender ought to be. These election processes need to be opened up so that more people can have the opportunity to find out about such vacancies, offer themselves as candidates, take part in the national selection process, and be nominated by states for TB vacancies. Having more nominations in a specific state with an open election process, and having more nominations from more states, will improve the quality and diversity of the members of the TBs. ${ }^{100}$ More competitive processes should result in more meritorious candidates at both the national level as well as at the international one.

A further problem relates to the overly political aspects of the electoral process, in terms of the typical candidate profile and the issues of campaigns and vote exchanging between states. There is in fact very little competition for some TB vacancies. Crucially, often nominations to TBs come from the same states and some states seem to have almost permanent slots in some TBs. Some states therefore seem to always have a representative on a specific TB, while others have representatives in many of these institutions. All of this weakens TBs and the process as a whole.

In fact, politics permeates the election process at the international level and 'elections to treaty bodies are largely based upon political, rather than expertise-based, considerations'. ${ }^{101}$ The problem of candidates' generally questionable level of expertise, as noted above, is further compounded by the fact that, at times, people nominated for TB membership work for the state in a variety of guises, which affects their independence and the quality of the work of TBs. ${ }^{102}$ If a candidate serves in an independent institution in their state, then there is less concern, but if they work in a government position (in whatever role), their independence cannot be assured. This type of problem is exacerbated by extensive and vigorous lobbying campaigns for election by some states and their candidates, often from places with lots of resources and more diplomatic and 
economic standing. This is bound to weaken the independence of nominees, who often meet with other state parties to try and elicit their vote. There is thus a need to try and reduce the overly political aspects of the electoral process. An interesting lesson could be drawn from the Aarhus Convention's non-compliance mechanism, 'which goes as far as excluding civil servants from membership in the compliance body altogether: this should avoid conflicts of interests from the outset'. ${ }^{103}$ It should therefore be an essential goal of the reform process, at both the national and international levels, to ensure that people elected to TBs are more representative of people around the world and that they come more often from victim groups and from groups that are usually excluded from these mechanisms. As was noted already in 2012, one of the goals of the review process for TBs is 'strengthening their work while fully respecting their independence'. ${ }^{104}$ Clearly, strengthening has to incorporate additional steps to promote greater independence.

\subsection{Involvement of civil society}

However, as important as these issues are, at present they are generally dealt with in limited ways in many nations. Many states also still do not involve their civil societies in state reporting, and when they do it is to a very limited extent. Far more ought to be done domestically to bring in these and other players, such as national human rights institutions (NHRIs) and courts, ${ }^{105}$ at all stages of the process. That will improve the process and make it more democratic. Civil society organisations also ought to be given clearer roles and proper responsibilities. They have to be sufficiently informed about what is occurring and being continually kept abreast of all the issues. The media, as a civil society actor, has a critical part to play in keeping the general public - as well as other civil society actors - informed, so that they can play a meaningful role in the process. However, the media has in many countries not been keeping a keen eye on these new processes, and therefore the public remains under-informed. It also means that parliamentary scrutiny is less likely, as parliament will not have had its consciousness raised about TB reporting and its importance. This lack of media attention allows the TB reporting process to be opaque and limits the ability of those who wish to engage with the process to do so.

In some ways, TBs should also be conducting regular and systematic due diligence processes ${ }^{106}$ when they deal with states, in order to find exactly who was involved in the reporting process and what consultations were held, with how many people, in what formats, at what times, and how views were incorporated into the state report. This should ensure that democratic participation is a right of people in states and that states need to take consultation and engagement seriously. Thus, there ought to be a questionnaire for all $\mathrm{TB}$ and other reporting processes that requests information about all phases of the consultation that were undertaken. States should also be questioned far more deeply on what consultation was conducted and this aspect of the reporting process ought not just be pro forma, but meaningful and engaging.

\section{Optimising the role of national reporting mechanisms}

As noted above, some of the recommendations made to improve the work of TBs are to get them to work better with states to enhance and improve their capacities with regard to 
their processes. Thus, national mechanisms, sometimes called national mechanisms for reporting and follow-up, operating in states are now being seen as critical to assist states with their reporting efforts. They are today being created rapidly in states all around the world. ${ }^{107}$

However, in many countries, these institutions generally remain closed, opaque and largely unknown outside the government. While some do have external representation, they are usually seen to be internal government mechanisms. Problematically, many are established in bureaucratic ways, often without sufficient discussion, consultation and public engagement. This is because governments usually want a process that they control, as well as because they are concerned about the way the state will be viewed externally, especially when it concerns human rights matters and matters that will come before the international community for scrutiny. However, even if such mechanisms are not NHRIs, ${ }^{108}$ and are really only internal governmental processes, their work and how they operate ought to be debated and consulted on, and views sought from outside government. This is because they deal with human rights issues and receive recommendations on such issues from outside the country, which means their work has repercussions outside the government and outside the country. They would benefit from civil society and academic input, especially from those with human rights knowledge and skills.

Indeed, transparency regarding the work and operation of national reporting mechanisms would be the democratic way of dealing with such issues. The whole process of state reporting, in fact, ought to be democratic and participatory, as this is a matter in which the public should have a key interest and role to play. ${ }^{109}$ This will enhance the process. Thus, even before the state reports to TBs, or to the Human Rights Council in Geneva for UPR, or to any other mechanism, there ought to be public consultation on the draft state report. This often does not happen. If there is consultation, very few people are consulted, and little, if any, time is given for meaningful input. However, public participation is a democratic right and is necessary. More needs to be done to encourage public engagement. As noted above, enhancing visibility can assist in this regard.

As a result of the greater appreciation for the need of better state reporting processes, more than 40 states have embarked on processes to set up national reporting mechanisms. ${ }^{110}$ They have often done so with UN assistance: as well as its training on treaties and state reporting, touched on above, the UN has also provided training on how to set up such institutions. However, the UN rarely mentions the importance of such bodies in its reports. In the UN SG's 2020 report on the status of TBs, only a few lines were devoted to national reporting mechanisms. ${ }^{111}$ The 2019 Position Paper of the Chairs of the Human Rights Treaty Bodies on the Future of the Treaty Body System $^{112}$ made no mention of such mechanisms, even where it was stated that '[a]ll treaty bodies currently receive alternative reports and undertake private meetings with stakeholders, including national human rights institutions, national preventive mechanisms, non-governmental organisations and others'. While the word 'others' could include these institutions, the fact that they are not explicitly mentioned is revealing of a lack of awareness or thought about them.

Thus, reforming the TB process ought to be also about improving the capacity at the national level to deal with TB reporting. This is already being done in some places. For 
example, the SG's 2020 report informed that the UN's capacity-building team had 'encouraged and assisted 24 states to establish new or strengthened national mechanisms for reporting and follow-up'. ${ }^{113}$ In fact, 43 states were assisted between 2015 and 2019 to establish or strengthen such mechanisms. However, many more states need to be supported in this regard.

The OHCHR has played a key role in the creation of some of these institutions and has produced a number of publications to assist in doing so. These include a Practical Guide and Study on National Mechanisms for Reporting and Follow-up (2016) and a Treaty Reporting Manual and Trainers Guide (2017). ${ }^{114}$ An internet training module was developed in 2018. The role of the OHCHR should however be to reach many more places and to enhance the ability of states to do state reporting better. The OHCHR should also further bolster the capacity and skills of civil society to play a meaningful role with these processes in their countries.

In this regard, a useful comparative example is the Kyoto Protocol to the UN Framework Convention on Climate Change (UNFCCC), which has a whole range of sophisticated methods to ensure compliance. ${ }^{115}$ One that has been determined to be key to ensuring compliance is capacity building. ${ }^{116}$ The focus on capacity building is an important lesson for state human rights oversight and compliance processes. Therefore, other processes have seen developed states agree to assist other states with resources to help them comply with their state reporting and compliance obligations. It was also recognised that many states had difficulties with reporting and specifically with drafting their national reports. ${ }^{117}$ Thus, an independent consultative group of experts was set up to assist states in this regard. ${ }^{118}$ Independent experts are further used when the national reports come in (besides the members of the committee): they conduct a second review after the Secretariat's initial review. This review can include visits to the state concerned, the goal being to ensure that the report contains accurate, consistent and relevant information. Thus, the use of independent experts, resources permitting, for the purposes of information verification and assessment can be extremely helpful in the TB process ${ }^{119}$ and should be considered for human rights TBs.

National reporting processes could also assist the TBs in other ways. While TBs and national mechanisms usually never meet, they actually should. They should be a key interface between TBs and the state. Members of national mechanisms ought to be part of the state's delegation that reports to a TB. They should then play a role in taking the recommendations of the TB back to their country and its national mechanism, in ensuring that the state does what has been recommended by the TB, and then in reporting back to the $\mathrm{TB}$ on what has been done in that regard.

Besides such responsibilities, these institutions

should be designed to lead consultations with NHRIs and NGOs on reporting and implementation; identify the relevant actors involved in implementation and guide them through the process; liaise with members of the judiciary to inform them of TB recommendations and collect and disseminate judicial decisions relevant to international human rights law. ${ }^{120}$

This is seldom done, as they usually only work inside governments. However, as a matter of course, these bodies should be consulting and engaging with a range of actors and stakeholders. This would improve the state reporting process as a whole. 
National reports to TBs should be reviewed by the national mechanism, as discussed above, before they are considered by the relevant TB. Technical assistance should be provided to states not only for the initial phase of the preparation of reports, but also in the phases thereafter, including during the follow-up and implementation stages. A further critical role is that of taking up recommendations from TBs and seeing that they are suitably implemented. While the High Commissioner's report stated that these mechanisms 'should further analyse and cluster recommendations from all human rights mechanisms, thematically, and/or operationally (according to the institution(s) responsible for implementing them), identify relevant actors involved in the implementation of the recommendations and guide them throughout the process' ${ }^{121}$ the UN should take the first responsibility to collect and group all of these recommendations together. ${ }^{122}$ This will allow a more holistic process to occur. It will also allow the process to be carried out quickly and efficiently, without a tendency to edit out, or to limit in some way, the proposals made to the state.

All of these proposals should then be placed on one publically accessible webpage to allow wider access and improve public awareness. Indeed, the Universal Human Rights Index - a searchable online database of the recommendations that have been made by TBs, through the UPR, and those developed by the special procedures of the Human Rights Council - already exists. This tool is extremely useful for disseminating information and ensuring greater engagement with these processes. However, it is not very well known and ought to be much more widely publicised. In general, quite apart from the index, there should be much greater dissemination of information to ensure that the public everywhere becomes better informed. One further suggestion would be for the UN to also, in addition to making all the information available on the website of TBs, and other mechanisms, create a webpage for each state that centralises the work of all the relevant bodies and reporting processes. This would allow a one-stop shop and promote accessibility. Another suggestion would be for funding so as to promote public access through technology. Although TBs do make information about their processes available on the internet, few people know that this information is available, and it is often hard to find, especially because the timetable of these processes is insufficiently advertised. Thus, the prominence and accessibility of TBs need to be dramatically enhanced to ensure that domestic processes are also given greater visibility. The more the TB processes are seen and understood, the greater the importance that will be accorded to the domestic processes that feed into these institutions. This is important as

it is clear that the weak aspect of the TBs as 'soft human rights reform partners' with their output not being legally binding turns out to be 'part of their essence and potential strength, namely, that they are diplomatic actors' with a strong ability to 'build habits and attitudes' of national actors towards improving human rights protection in their states. ${ }^{123}$

Another particularly useful system, currently being trialled under the capacity-building programme of the UN in six pilot projects in Botswana, Mauritius, Montenegro, Saudi Arabia, Sierra Leone and Palestine, is the creation of national recommendations tracking databases. ${ }^{124}$ These should be vital to the domestic reporting and follow-up processes in those states, and should therefore be rolled out more widely, particularly in the developing world, where human rights protection needs to be enhanced more quickly. 
Yet this is not to argue that developed countries should not embark on these processes as well; indeed, there is a need for them in every state. Such databases should help in the process of increasing knowledge of and access to these processes both externally and internally.

While a lot more emphasis ought to be placed on states in the reporting, the process can also be assisted if TBs also assist states in the process of ensuring state compliance. Proposals to promote compliance include having a dedicated person in a TB, or a unit connected to TBs as a whole, to deal with states. TBs could also have more follow-up processes, led by rapporteurs. A grading formula could be introduced to actually determine and compare states on their achievements. TBs could also conduct visits to the states to enhance the state reporting process. All of these could be done to ensure a greater working relationship between states and TBs on an ongoing basis and to enhance the cooperation and outcomes of the TB process.

\section{Conclusion}

The UN's current review of the treaty process will have important ramifications for the future, regardless of whether the reforms implemented are major or minor. Even if little is done to deal with issues of resources and a host of other matters, we may continue to see TB processes weakened and less able to do what they were established to do. The context in which the review is taking place is important, in that many states have expressed a wish to reduce the onerous nature of the oversight and compliance processes.

While there are problems with TBs and the reporting processes as a whole, some of these difficulties are quite directly related to what states do and the resource constraints imposed by states. These constraints are really the doing of state parties, which have not, often deliberately, sought to increase the budgets available for the TB process. However, there are other issues as well that should enhance the effectiveness of TBs such as enhancing their independence. These are also in the purview of states.

Various reforms have already been implemented to harmonise the processes across all the TBs and to make them more coherent and easier to comply with. Despite this, TB reform continues to be seen by states as an issue of major importance. No doubt reforms are still necessary, but the critical issue should be ensuring that such reforms do not in fact reduce the efficacy or impact of the TB process. If they do, this will have dire consequences for the protection of human rights. Significantly, rather than focusing entirely on the TB process at the international level, greater attention ought to be given to how the reporting process at the domestic level can be enhanced to provide greater input and support to TBs and the work they do. All the problems that have been raised about TBs and their processes can be at least somewhat negated by establishing functional democratic national mechanisms that would improve what states do to prepare for the reporting process and the quality of state reports. Having a national mechanism will also enhance how the recommendations from TBs are received and implemented.

If domestic mechanisms are to really be effective and play the role they ought to, they need to be set up appropriately, function well and be adequately resourced. Their role 
needs to be expanded in many places around the world and they need to be more visible and participatory. Well-functioning national mechanisms are fundamental not only to the work of TBs but also to the promotion of human rights in their states. The more of these mechanisms there are, and the better they work, the easier the work of TBs will be, and the greater the impact TBs will have on ensuring that states improve their human rights promotion and protection efforts.

\section{Notes}

1. There are however more than 80 international human rights treaties, declarations and other international human rights laws. This is besides other international laws that are applicable in a range of different fields, for example, international humanitarian law and international criminal law. The human rights treaty bodies are the Committee on the Elimination of Racial Discrimination (CERD), the Committee on Economic, Social and Cultural Rights (CESCR), the Human Rights Committee (CCPR), the Committee on the Elimination of Discrimination against Women (CEDAW), the Committee Against Torture (CAT), the Committee on the Rights of the Child (CRC), the Committee on Migrant Workers (CMW), the Subcommittee on Prevention of Torture and other Cruel, Inhuman or Degrading Treatment or Punishment (SPT), the Committee on the Rights of Persons with Disabilities (CRPD) and the Committee on Enforced Disappearances.

2. The Committee on the Elimination of Racial Discrimination, the Human Rights Committee, the Committee on Economic, Social and Cultural Rights, the Committee on the Elimination of Discrimination against Women, the Committee against Torture, the Subcommittee on Prevention of Torture, Committee on the Rights of the Child, the Committee on the Protection of the Rights of All Migrant Workers and Members of Their Families, the Committee on the Rights of Persons with Disabilities, and the Committee on Enforced Disappearances.

3. Letter from the President of the Seventy-fourth Session of General Assembly, Tijjani Muhammad-Bande, Permanent Representative of Nigeria, to States, 8 April 2020. https:// www.ohchr.org/Documents/HRBodies/TB/LetterPG8Aapr20.pdf.

4. See Valentina Carraro, 'Promoting Compliance with Human Rights: The Performance of the UN Universal Periodic Review and Treaty Bodies', International Studies Quarterly 63, no. 4 (2019): 1079-1093.

5. On issues about why states ratify treaties see Oona A. Hathaway, 'Why Do Countries Commit to Human Rights Treaties?', Journal of Conflict Resolution 51 (2007): 588.

6. A. Abashidze, 'The Complementary Role of General Comments in Enhancing the Implementation of Treaty Bodies' Recommendations and Views (The Example of CESCR)', in New Challenges for the UN Human Rights Machinery. What Future For the UN Treaty Body System and the Human Rights Council Procedures?, eds M. Bassiouni and W. Schabas (Antwerp: Intersentia Publishers, 2011), 137-149.

7. Efraim Chalamish, 'Do Treaties Matter? On Effectiveness and International Economic Law', Michigan Journal of International Law 32 (2011): 325.

8. Eric Neumayer, 'Do International Human Rights Treaties Improve Respect for Human Rights?', Journal of Conflict Resolution 49, no. 6 (2005): 925-953.

9. The TBs that can do this are CAT (Article 20), CEDAW (Article 8) CEDAW Optional Protocol, CRPD (Article 6), CPRD Optional Protocol to CRPD, CED (Article 33), CESCR (Article 11) CESCR Optional Protocol, the CRC (Article 13), and in terms of the CRC Optional Protocol. Other TBs have other procedures including, for example, the CED that uses an urgent action methodology if someone is disappeared. This allows the CED to react quickly. This is similar to the process used by the Special Procedures mechanism, the Working Group on Enforced and Involuntary Disappearances.

10. Kate Fox Principi, 'United Nations Individual Complaint Procedures - How Do States Comply?', Human Rights Law Journal 1 (2017): 37. 
11. See M. O’Flaherty, 'The Concluding Observations of United Nations Human Rights Treaty Bodies', Human Rights Law Review 6 (2006): 27-52.

12. Rosanne van Alebeek and Andre Nollkaemper, 'The Legal Status of Decisions by Human Rights Treaty Bodies in National Law', in UN Human Rights Treaty Bodies: Law and Legitimacy, eds Helen Keller and Geir Ulfstein (Cambridge: Cambridge University Press, 2012).

13. C. P. Romano, 'A Taxonomy of International Rule of Law Institutions', Journal of International Dispute Settlement 2, no. 1 (2011): 241-277.

14. Wade M. Cole, 'Sovereignty Relinquished? Explaining Commitment to International Human Rights Covenants 1966-1999', American Sociological Review 70, no. 3 (2005): 472-495.

15. A. Cassese, International Law (Oxford: Oxford University Press, 2005), 98.

16. F. R. Jacur, 'Triggering Non-Compliance Procedures', in Non-Compliance Procedures and Mechanisms and the Effectiveness of International Environmental Agreements, eds T. Treves, A. Tanzi, L. Pineschi, C. Pitea and C. Ragni (The Hague: T.M.C. Asser Press, 2009), 373-388.

17. G. Ulfstein, T. Marahun and A. Zimmermann, eds, Making Treaties Work: Human Rights, Environment and Arms Control (Cambridge: Cambridge University Press, 2007), 1.

18. See further Thomas Risse, Stephen C. Ropp and Kathryn Sikkink, eds, The Persistent Power of Human Rights: From Commitment to Compliance (Cambridge: Cambridge University Press, 2013).

19. J. Sarkin, 'A Critique of the Decision of the African Commission on Human and Peoples' Rights Permitting the Demolition of the SADC Tribunal: Politics versus Economics and Human Rights', African Journal of International and Comparative Law 24, no. 2 (2016): 215-241.

20. M. R. Madsen, P. Cebulak and M. Wiebusch, 'Backlash Against International Courts: Explaining the Forms and Patterns of Resistance to International Courts', International Journal of Law in Context 14, no. 2 (2018): 197-220.

21. Rwanda, Tanzania, Cote D’Ivoire and Benin.

22. On regional mechanisms in Africa see Jeremy Sarkin, 'The African Commission on Human and Peoples' Rights and the Future African Court of Justice and Human Rights: Comparative Lessons from the European Court of Human Rights', South African Journal of International Affairs 18, no. 3 (2011): 284. On the need to reform these processes see Jeremy Sarkin, 'Why the Role of the African Commission on Human and Peoples' Rights in Advancing Democratic Principles and Human Rights in African Countries Needs to be Reformed: An Examination Using the Lens of Swaziland/eSwatini', Southern African Public Law 32, no. 1 (2019): 1-56.

23. J. Sarkin, 'A Critique of the Decision of the African Commission on Human and Peoples' Rights Permitting the Demolition of the SADC Tribunal: Politics versus Economics and Human Rights', African Journal of International and Comparative Law 24, no. 2 (2016): 215-241.

24. A. Hofmann, 'Resistance Against the Court of Justice of the European Union', International Journal of Law in Context 14, no. 2 (2018): 258-274; and M. R. Madsen, 'Rebalancing European Human Rights: Has the Brighton Declaration Engendered a New Deal on Human Rights in Europe?', Journal of International Dispute Settlement 9, no. 2 (2018): 199-222.

25. J. Gathii, 'Mission Creep or a Search for Relevance: The East African Court of Justice's Human Rights Strategy', Duke Journal of Comparative and International Law 24 (2014): 249-296.

26. G. Shaffer, M. Elsig and S. Puig, 'The Extensive (but Fragile) Authority of the WTO Appellate Body', Law and Contemporary Problems (2015): 15-17.

27. J. Sarkin, 'The Need to Reform the Political Role of the African Union (AU) in Promoting Democracy and Human Rights in Domestic States: Making States More Accountable and Less Able to Avoid Scrutiny at the United Nations and at the AU, Using Swaziland to 
Spotlight the Issues', African Journal of International and Comparative Law 26, no. 1 (2018): 84-107.

28. Eric A. Posner, The Twilight of Human Rights Law (Oxford: Oxford University Press, 2014), 77.

29. O. A. Hathaway, 'Do Human Rights Treaties Make a Difference?', The Yale Law Journal 111, no. 8 (2002): 1935-2042, 1938.

30. Ibid., 2000.

31. Vera Shikhelman, 'Implementing Decisions of International Human Rights InstitutionsEvidence from the United Nations Human Rights Committee', European Journal of International Law 30, no. 3 (2019): 753-777.

32. Suzanne Egan, 'Strengthening the United Nations Human Rights Treaty Body System', Human Rights Law Review 13, no. 2 (2013): 209-243.

33. Open Society Justice Initiative, From Judgment to Justice: Implementing International and Regional Human Rights Decisions (Open Society Justice Initiative, 2010), 117-132. https:// www.justiceinitiative.org/uploads/62da1d98-699f-407e-86ac-75294725a539/from-judgment -to-justice-20101122.pdf.

34. See generally Anja Seibert-Fohr, 'The Human Rights Committee - Legacy and Promise', in International Human Rights. Human Rights Institutions, Tribunals, and Courts- Legacy and Promise, ed. Gerd Oberleitner (Singapore: Springer 2018): 117-142.

35. Open Society Justice Initiative, From Judgment to Justice, 120.

36. Anne Bayefsky, 'The UN Human Rights Treaty System: Universality at the Crossroads' (April 2001), 33. www.bayefsky.com/report/finalreport.pdf.

37. Open Society Justice Initiative, From Judgment to Justice, 117-132.

38. Wade M. Cole, 'Institutionalizing Shame: The Effect of Human Rights Committee Rulings on Abuse, 1981-2007', Social Science Research 41 (2012): 539, 540.

39. Murat Metin Hakki, 'The Silver Anniversary of the UN Human Rights Committee: Anything to Celebrate?', The International Journal of Human Rights 6 (2002): 85, 87.

40. See further Alebeek and Nollkaemper, 'The Legal Status of Decisions by Human Rights Treaty Bodies', 356-413.

41. Abram Chayes and Antonia Handler Chayes, The New Sovereignty: Compliance with International Regulatory Agreements (Cambridge, MA: Harvard University Press, 1995), 9.

42. Thomas Buergenthal, 'The U.N. Human Rights Committee', Max Planck Year Book of United Nations Law 5 (2001): 341-398, 397.

43. Yvonne M. Dutton, 'Explaining State Commitment to the International Criminal Court: Strong Enforcement Mechanisms as a Credible Threat', Washington University Global Studies Law Review 10 (2011): 477, 482.

44. Geneva Academy, Optimizing the UN Treaty Body System: Academic Platform Report on the 2020 Review (May 2018), 38-39. https://www.geneva-academy.ch/joomlatools-files/ docman-files/Optimizing\%20UN\%20Treaty\%20Bodies.pdf.

45. See some of the issues in M. O'Flaherty and P. Tsai, 'Periodic Reporting: The Backbone of the UN Treaty Body Review Procedures', in New Challenges for the UN Human Rights Machinery: What Future for the UN Treaty Body System and the Human Rights Council Procedures?', eds M. Cherif Bassiouni and W. A. Schabas (Cambridge: Intersentia, 2012): 37-56.

46. Aslan Abashidze and Aleksandra Koneva, 'The Process of Strengthening the Human Rights Treaty Body System: The Road Towards Effectiveness or Inefficiency?', Netherlands International Law Review 66, no. 3 (2019): 357-389.

47. Egan, 'Strengthening the United Nations Human Rights Treaty Body System'.

48. Nick Cumming-Bruce, 'Budget Cuts May Undercut the U.N.'s Human Rights Committees', New York Times, May 24, 2019.

49. Navi Pillay, Treaty Bodies: No More Tinkering: Real Reform Needed to UN Human Rights Treaty Monitoring (Geneva: International Service for Human Rights, 2019). https://www. ishr.ch/news/treaty-bodies-no-more-tinkering-real-reform-needed-un-human-rights-treaty -monitoring. 
50. Michael O'Flaherty and Claire O'Brien, 'Reform of UN Human Rights Treaty Monitoring Bodies: A Critique of the Concept Paper on the High Commissioner's Proposal for a Unified Standing Treaty Body', Human Rights Law Review 7, no. 1 (2007): 141, 142.

51. Cosette D. Creamer and Beth A. Simmons, 'Ratification, Reporting, and Rights: Quality of Participation in the Convention Against Torture', Human Rights Quarterly 37, no. 3 (2015): 579-608, 584.

52. N. S. Rodley, 'The Role and Impact of Treaty Bodies', in The Oxford Handbook of International Human Rights Law, ed. D. Shelton (Oxford: Oxford University Press, 2013): 621-648.

53. United Nations Secretary-General, 'Harmonized Guidelines on Reporting Under the International Human Rights Treaties, Including Guidelines on a Common Core Document and Treaty-Specific Documents', 10 May, HRI/ MC/ 2006/ 3; and United Nations OHCHR, Compilation of Guidelines on the Form and Content of Reports to be Submitted by States Parties to the International Human Rights Treaties (Geneva: OHCHR, 2006), HRI/GEN/ 2/ Rev.6.

54. Cosette D. Creamer and Beth A. Simmons, 'The Proof is in the Process: Self-Reporting Under International Human Rights Treaties', American Journal of International Law 114, no. 1 (2020): 1-50.

55. L. Oette, 'The UN Human Rights Treaty Bodies: Impact and Future', in International Human Rights Institutions, Tribunals, and Courts, ed. G. Oberleitner (Singapore: Springer, 2020), 95-115.

56. Statement of Ms Navanethem Pillay, United Nations High Commissioner for Human Rights at the 12th Session of the Human Rights Council, 14th September 2009. https://newsarchive. ohchr.org/EN/NewsEvents/Pages/DisplayNews.aspx?NewsID=87\&LangID=E.

57. United Nations General Assembly, Strengthening and Enhancing the Effective Functioning of the Human Rights Treaty Body System (New York: UNGA, 2014), UN Doc. A/RES/68/268 (9 April 2014).

58. See further S. Subedi, Effectiveness of the UN Human Rights System: Reform and the Judicialisation of Human Rights (Abingdon: Routledge, 2017).

59. See for example O’Flaherty and O’Brien, 'Reform of UN Human Rights Treaty Monitoring Bodies', 141-172.

60. G. Oberleitner, 'Agenda for Strengthening Human Rights Institutions', in International Human Rights Institutions, Tribunals, and Courts, ed. G. Oberleitner (Singapore: Springer, 2018), 551-569.

61. Egan, 'Strengthening the United Nations Human Rights Treaty Body System', 214.

62. L. R. Helfer, 'Pushback against Supervisory Systems: Lessons for the ILO from International Human Rights Institutions', in Law For Social Justice, eds George P. Politakis et al. (Geneva: International Labour Office, 2019), 257-278.

63. United Nations Human Rights Council, Non Paper for the 2020 Review of the UN Human Rights Treaty Bodies System, Submitted by Costa Rica and 43 Other States (20 June 2019) to the 31st Meeting of Chairpersons (24-28 June 2019, New York). https://tbinternet.ohchr. org/_layouts/15/treatybodyexternal/Download.aspx?symbolno=INT/CHAIRPERSONS/CHR /31/28571\&Lang=en.

64. Creamer and Simmons, 'The Proof is in the Process', 30.

65. N. Goeteyn and F. Maes, 'Compliance Mechanisms in Multilateral Environmental Agreements: An Effective Way to Improve Compliance?', Chinese Journal of International Law 10 (2011): 791-826, 826.

66. On the issue of effectiveness see Wade M. Cole, 'Human Rights as Myth and Ceremony? Reevaluating the Effectiveness of Human Rights Treaties 1981-2007', American Journal of Sociology 117 (2012): 1131.

67. Navi Pillay, Treaty Bodies: No More Tinkering: Real Reform Needed to UN Human Rights Treaty Monitoring (Geneva: International Service for Human Rights, 2019). https://www. ishr.ch/news/treaty-bodies-no-more-tinkering-real-reform-needed-un-human-rights-treaty -monitoring. 
68. J. Krommendijk, The Domestic Impact and Effectiveness of the Process of State Reporting Under UN Human Rights Treaties in the Netherlands, New Zealand and Finland: PaperPushing or Policy Prompting? (Cambridge: Intersentia, 2014); and Cole, 'Human Rights as Myth and Ceremony?.

69. Emilie M. Hafner-Burton and Kiyoteru Tsutsui, 'Justice Lost! The Failure of International Human Rights Law to Matter Where Needed Most', Journal of Peace Research 44, no. 4 (2007): 407-425.

70. On enforcement see Harold Hongju Koh, 'How Is International Human Rights Law Enforced?', Indiana Law Journal 74 (1999): 1397.

71. Abashidze and Koneva, 'The Process of Strengthening the Human Rights Treaty Body System'.

72. Miriam Newman-Tancredi, 'The Need for Reform of the United Nations' Human Rights Treaty System', Exeter Student Law Review 1 (2015): 41.

73. See further I. Truscan, The Independence of UN Human Rights Treaty Body Members (Geneva: Geneva Academy of International Humanitarian Law and Human Rights, 2012).

74. See for example Annemarie Devereux and Catherine Anderson, 'Reporting Under International Human Rights Treaties: Perspectives from Timor Leste's Experience of the Reformed Process', Human Rights Law Review 8, no. 1 (2008): 69-104.

75. See generally on the need to schedule TB reviews differently Y. Shany and S. Cleveland, Treaty Body Reform 2020: Has the Time Come for Adopting a Global Review (Geneva: Geneva Academy, 2017). https://www.geneva-academy.ch/joomlatools-files/docman-files/ Draft\%20List\%20of\%20Submissions\%20-\%20Academic\%20Platform\%202020\%20Review\% 20without\%20Propositions\%20.pdf.

76. Egan, 'Strengthening the United Nations Human Rights Treaty Body System'.

77. Geneva Academy, Optimizing the UN Treaty Body System, 7.

78. Icelandic Human Rights Centre, International Supervisory Mechanisms for Human Rights (no date). http://www.humanrights.is/en/human-rights-education-project/human-rightsconcepts-ideas-and-fora/part-i-the-concept-of-human-rights/international-supervisory-mec hanisms-for-human-rights.

79. Christen Broecker and Michael O’ Flaherty, The Outcome of the General Assembly's Treaty Body Strengthening Process: An Important Milestone on a Longer Journey (Geneva: Universal Rights Organisation, 2014), 7. http://www.universal-rights.org/wpcontent/uploads/2015/ 02/URG_Policy_Brief_web_spread_hd.pdf.

80. Christof H. Heyns and Frans J. Viljoen, 'The Impact of the United Nations Human Rights Treaties on the Domestic Level', Human Rights Quarterly 23 (2001): 483, 485.

81. United Nations Office of the High Commissioner for Human Rights, Concept Paper on the High Commissioner's Proposal for a Unified Standing Treaty Body: Report by the Secretariat, U.N. Doc. HRI/MC/2006/2 (22 March 2006), 10.

82. Creamer and Simmons, 'Ratification, Reporting, and Rights', 581.

83. Ibid., 584 .

84. Klaus Dieter Beiter, The Protection of the Right to Education by International Law: Including a Systematic Analysis of Article 13 of the International Covenant on Economic, Social and Cultural Rights (Leiden: Martinus Nijhoff Publishers, 2006), 605.

85. On the problems of implementation see Heli Niemi, 'National Implementation of Findings by United Nations Human Rights Treaty Bodies: A Comparative Study', Research Reports Åbo Akademi University 20 (2003).

86. On issues around increasing the effectiveness of recommendations, see Jasper Krommendijk, 'The Domestic Effectiveness of International Human Rights Monitoring in Established Democracies: The Case of the UN Human Rights Treaty Bodies', Review of International Organizations 10, no. 4 (2015): 489-512.

87. Jeremy Sarkin, 'The Role of National Human Rights Mechanisms for Reporting and FollowUp (NMRF): Understanding These New Global Domestic Processes Using Georgia and Portugal as a Focus', Teise: Vilnius University Scholarly Journal of Law 112 (2019): 168-189.

88. Pillay, Treaty Bodies: No More Tinkering. 
89. United Nations Press Release, Human Rights: UN Treaty Body Chairpersons Envision a Stronger, Simpler Monitoring System (4 July 2019). https://www.ohchr.org/EN/ NewsEvents/Pages/DisplayNews.aspx?NewsID=24787\&LangID=E. See also Position Paper of the Chairs of the Human Rights Treaty Bodies on the Future of the Treaty Body System Adopted at 31st Meeting of Chairpersons (24-28 June 2019, New York). https:// www.ohchr.org/Documents/HRBodies/TB/AnnualMeeting/31Meeting/AnnexIII_A_74_256 _Vision_Chairs.docx

90. Geneva Academy, Optimizing the UN Treaty Body System.

91. Chayes and Chayes, The New Sovereignty, 25.

92. Sarkin, 'The Role of National Human Rights Mechanisms'.

93. United Nations OHCHR, Human Rights Indicators: A Guide to Measurement and Implementation (Geneva: OHCHR, 2012). See further Gauthier De Beco, 'Human Rights Indicators for Assessing State Compliance with International Human Rights', Nordic Journal of International Law 77, no. 1-2 (2008): 23-49.

94. United Nations OHCHR, Strengthening the United Nations Human Rights Treaty Body System: A Report by the United Nations High Commissioner for Human Rights, 26 June 2012 (Geneva: OHCHR, 2012).

95. John Morijn, 'Reforming United Nations Human Rights Treaty Monitoring Reform', Netherlands International Law Review 58 (2011): 295, 299.

96. United Nations OHCHR, Report on Indicators for Promoting and Monitoring the Implementation of Human Rights (Geneva: OHCHR, 2008). http://www2.ohchr.org/english/issues/ indicators/docs/HRI.MC.2008.3_en.pdf.

97. United Nations General Assembly, Status of the Human Rights Treaty Body System: Report of the Secretary-General, 10 January 2020, A/74/643, para. 17.

98. See generally Abhinav Chandrachud, 'Diversity and the International Criminal Court: Does Geographic Background Impact Decision Making?', Brooklyn Journal of International Law 38, no. 2 (2013): 1.

99. On how political appointments weaken institutions see Jeremy Sarkin and Ram Kumar Bandari, 'Why Political Appointments to Truth Commissions Cause Difficulties for These Institutions: Using the Crisis in the Transitional Justice Process in Nepal to Understand How Matters of Legitimacy and Credibility Undermine Such Commissions', Journal of Human Rights Practice 11, no. 3 (2020): 1-27.

100. On the role of committee members of TBs see Gerald L. Neuman, 'Giving Meaning and Effect to Human Rights: The Contributions of Human Rights Committee Members', in The UN Human Rights Covenants at 50, eds Daniel Moeckli and Helen Keller (Oxford: Oxford University Press, 2018), 4.

101. Valentina Carraro, 'Electing the Experts: Expertise and Independence in the UN Human Rights Treaty Bodies', European Journal of International Relations 25, no. 3 (2019): 826851,842 .

102. Carraro, 'Electing the Experts'.

103. Alessandro Fodella, 'Structural and Institutional Aspects of Non-Compliance Mechanisms', in Non-Compliance Procedures and Mechanisms and the Effectiveness of International Environmental Agreements, eds T. Treves, A. Tanzi, L. Pineschi, C. Pitea and C. Ragni (The Hague: T.M.C. Asser Press, 2009), 355-372, 363.

104. United Nations OHCHR, Strengthening the United Nations Human Rights Treaty Body System, 9.

105. On the role that NHRIs should play with TBs see D. Zipoli, 'National Human Rights Institutions and the United Nations Human Rights Treaty Body System: A Rebuttal to the Sceptics', in National Human Rights Institutions in Southeast Asia, eds James Gomez and Robin Ramcharan (Singapore: Palgrave Macmillan, 2020), 55-80. On the role of the courts with the state reporting process see Machiko Kantetake, 'UN Human Rights Treaty Monitoring Bodies before Domestic Courts', International and Comparative Law Quarterly 67 (2018): 201. 
106. Jeremy Sarkin, 'A Methodology to Ensure that States Adequately Apply Due Diligence Standards and Processes to Significantly Impact Levels of Violence Against Women Around the World', Human Rights Quarterly 40, no. 1 (2018): 1-36.

107. Sarkin, 'The Role of National Human Rights Mechanisms'.

108. On NHRIs see Katerina Linos and Tom Pegram, 'Architects of their Own Making: National Human Rights Institutions and the United Nations', Human Rights Quarterly 38 (2016): 1109.

109. Mark R. Goldschmidt, 'The Role of Transparency and Public Participation in International Environmental Agreements: The North American Agreement on Environmental Cooperation', Boston College Environmental Affairs Law Review 29 (2002): 343, 348.

110. Sarkin, 'The Role of National Human Rights Mechanisms'.

111. United Nations General Assembly, Status of the Human Rights Treaty Body System.

112. Position Paper of the Chairs of the Human Rights Treaty Bodies on the Future of the Treaty Body System Adopted at 31st Meeting of Chairpersons (24-28 June 2019, New York). https://www.ohchr.org/Documents/HRBodies/TB/AnnualMeeting/31Meeting/AnnexIII_ A_74_256_Vision_Chairs.docx.

113. United Nations General Assembly, Status of the Human Rights Treaty Body System.

114. Sarkin, 'The Role of National Human Rights Mechanisms'.

115. J. Bulmer, 'Compliance Regimes in Multilateral Environmental Agreements', in Promoting Compliance in an Evolving Climate Regime, eds J. Brunnee, M. Doelle and L. Rajamani (Cambridge: Cambridge University Press, 2012), 66.

116. A. Tanzi and C. Pitea, 'Non-Compliance Mechanisms: Lessons Learned and the Way Forward', in Non-Compliance Procedures and Mechanisms and the Effectiveness of International Environmental Agreements, eds T. Treves, A. Tanzi, L. Pineschi, C. Pitea and C. Ragni (The Hague: T.M.C. Asser Press, 2009), 569-580.

117. Neumayer, 'Do International Human Rights Treaties Improve Respect for Human Rights?', 925.

118. Xueman Wang and Glenn Wiser, 'The Implementation and Compliance Regimes Under the Climate Change Convention and Its Kyoto Protocol', Review of European Community and International Environmental Law 11 (2002): 181, 185.

119. On the role independent experts could play see M. Ambrus, K. Arts, E. Hey and H. Raulus, 'The Role of Experts in International and European Decision-Making Processes: Setting the Scene', in The Role of 'Experts' in International and European Decision-Making Processes: Advisors, Decision Makers or Irrelevant Actors?, eds M. Ambrus, K. Arts, E. Hey and H. Raulus (Cambridge: Cambridge University Press, 2014), 1-16.

120. Egan, 'Strengthening the United Nations Human Rights Treaty Body System'.

121. United Nations OHCHR, Strengthening the United Nations Human Rights Treaty Body System, 85.

122. See generally M. Limon and M. Montoya, Clustering and the Integrated Implementation of Recommendations: The Key to Unlocking the Complementary Power of the UN's Compliance Mechanisms (Geneva: Universal Rights Group, 2019). https://www.universal-rights.org/wpcontent/uploads/2019/06/Clustering_and_the_integrate_planches_2.pdf.

123. Abashidze and Koneva, 'The Process of Strengthening the Human Rights Treaty Body System', 361.

124. United Nations General Assembly, Status of the Human Rights Treaty Body System.

\section{Disclosure statement}

No potential conflict of interest was reported by the author(s).

\section{Notes on contributor}

Jeremy Sarkin is Distinguished Visiting Professor of Law at Nova University of Lisbon (Portugal) and a Research Fellow in the Department of Criminology at the University of the Free State in 
South Africa. He has undergraduate and postgraduate law degrees from South Africa, a Master of Laws degree from Harvard Law School and a Doctor of Laws degree on comparative and international law. He is admitted to practise as an attorney in the USA and South Africa. He was Chairperson-Rapporteur of the United Nations Working Group on Enforced or Involuntary Disappearances. He served as an acting judge in 2002 and 2003 in the High Court in South Africa. He is also a member of a number of journal editorial boards. He has published 19 books and more than 300 articles. Some of his books are The Global Impact and Legacy of Truth Commissions (Intersentia 2019); Germany's Genocide of the Herero (UCT Press 2011); Reparations for Colonial Genocides (Praeger 2009); Human Rights in African Prisons (Ohio University Press 2008); Reconciliation in Divided Societies: Finding Common Ground (University of Pennsylvania Press 2007); and Carrots and Sticks: The TRC and the South African Amnesty Process (Intersentia 2004).

\section{ORCID}

Jeremy Sarkin (D) http://orcid.org/0000-0002-9424-6874 